\title{
POTRET PENDIDIKAN MORAL DALAM NOVEL MERPATI BIRU KARYA ACHMAD MUNIF \\ THE PORTRAIT OF MORAL EDUCATION THROUGH THE NOVEL "BLUE DOVE” BY ACHMAD MUNIF
}

\author{
Basuki Sarwo Edi \\ Balai Bahasa Sumatera Selatan \\ Jalan Seniman Amri Yahya Komplek Dekranasda Seberang Ulu I \\ Jakabaring Palembang \\ basukisarwoedi@yahoo.co.id
}

\begin{abstract}
This study aimed to describe the portrait of moral education through the novel "Blue Dove" by Achmad Munif, a picture of human life. Benefits Novel studies reveal facts as a source of public education. With novel reading materials can be used as study materials. Sources used in this study is novel Pigeons Blue Achmad Munif work. The method used deskriprif method.

The results obtained in this study indicate that the novel Pigeons Blue Achmad Munif work has a theme of environmental influences determine the character "a figure Ken" in the struggle to survive, to struggle and hard work.
\end{abstract}

Keywords: novel, moral and education

\begin{abstract}
Abstrak
Penelitian ini bertujuan mendeskripsikan potret pendidikan moral melalui novel "Merpati Biru" karya Achmad Munif, sebuah gambaran kehidupan manusia. Manfaat penelitian mengungkapkan fakta novel sebagai sumber pendidikan masyarakat. Dengan bahan bacaan novel dapat digunakan sebagai bahan kajian pembelajaran menghadpi permasalahan hidup. Adapun sumber yang digunakan dalam penelitian ini adalah novel Merpati Biru karya Achmad Munif. Metode yang digunakan metode deskriprif.

Hasil yang diperoleh dalam penelitian ini menunjukkan bahwa novel Merpati Biru karya Achmad Munif memiliki tema pengaruh lingkungan menentukan watak "seorang tokoh Ken" dalam perjuangan mempertahankan hidupnya, perlu perjuangan dan kerja keras.
\end{abstract}

Kata Kunci: novel, moral dan pendidikan

\section{Pendahuluan}

Pada prinsipnya, penulis sebuah novel menciptakan karya sastra adalah untuk bisa dinikmati, dipahami, dan dimanfaatkan para penikmat karya sastra demi kemandirian. Banyak karya sastra yang dihasilkan para penulis yang bisa dijadikan acuan untuk pembelajaran dan bermanfaat dalam kehidupan bagi para penikmat karya sastra. Para penikmat karya sastra harus sadar bahwa menikmati sebuah karya sastra tidak hanya menikmati keindahan cerita yang ada dalam karya sastra, tetapi bisa juga menikmati makna yang terkandung di dalamnya.

Novel merupakan karya fiksi. Sebagai karya sastra, novel tidak berangkat dari suatu yang kosong tiada arti. Hal ini terjadi karena novel menceritakan berbagai masalah kehidupan manusia dalam interaksinya dengan lingkungan dan sesama, interaksinya dengan diri sendiri, serta interaksinya dengan Tuhan. Novel merupakan hasil dialog kontemplasi dan reaksi pengarang terhadap lingkungan dan kehidupan. Oleh karena itu, bagaimanapun 
novel merupakan sebuah cerita dan karenanya terkandung juga di dalamnya tujuan memberi manfaat, dalam novel akan ditemukan pesan yang ditujukan kepada pembaca, memberikan hiburan. Pesan atau amanat yang terkandung di dalam novel disebut moral.

Melalui novel, penikmat karya sastra mendapatkan ilmu guna memantapkan diri dalam menapaki kehidupan dan mendapatkan tambahan bekal memperbaiki diri dari beberapa contoh nyata dalam karya sastra. Kelemahankelemahan yang kita miliki bisa kita perbaiki dari contoh-contoh yang ada dalam cerita. Kesalahan-kesalahan apa yang pernah terjadi pada diri kita bisa kita perbaiki dan kita pecahkan berdasarkan pembelajaran dari tokoh-tokoh yang ada dalam cerita. Rahmanto dalam bukunya (1988:16) menulis bahwa manfaat karya sastra bagi pembacanya, antara lain: (1) memberi kesadaran kepada pembaca tentang kebenarankebenaran hidup ini, (2) memberi kegembiraan dan kepuasan batin, (3) memenuhi kebutuhan manusia terhadap naluri keindahan seninya, dan (4) menjadikan manusia berbudaya.

Selain manfaat yang telah dikemukakan pada pernyataan sebelumnya, bahwa karya sastra juga bisa dijadikan acuan untuk pedoman hidup, karya sastra yang baik dan berbobot akan mampu membawa pembacanya ke arah yang lebih baik sehingga pembaca tersebut mampu memiliki kepribadian yang unggul dan bermartabat. Hal ini dapat terjadi karena penikmat sastra tersebut mampu menyerap hal-hal positif yang ada dalam karya sastra sehingga dirinya tidak akan terhanyut dalam arus buruk yang deras yang akan menghancurkan masa depannya. Biasanya, para penulis karya sastra selain menampilkan permasalahan-permasalahan sosial kehidupan, juga akan menampilkan solusi yang ada sehingga apa saja yang dibutuhkan penikmat karya sastra akan terpenuhi.

Dalam novel yang berjudul Merpati Biru, pengarang memiliki tujuan khusus yang hendak disampaikan kepada para penikmat karya sastra. Akibat adanya pesan khusus yang hendak disampaikan pembaca maka penampilan cerita novel dibuat sedemikian apiknya. Tujuannya agar penikmat karya sastra tidak bosan untuk menikmati karya sastra tersebut.

Pengarang memiliki pandangan ke depan bahwa apa yang ia buat harus memiliki manfaat yang begitu penting untuk pembacanya sehingga apa yang pengarang ciptakan tidak hanya sanggup menjadi alat hiburan semata, tetapi karya ciptaanya sanggup sebagai sarana pendidikan, khususnya pendidikan mental. Penulis novel mengambil judul Merpati Biru bukan sekadar judul, melainkan merupakan bentuk dari sikap dan sifat binatang yang bernama merpati bukan tanpa sebab. Alasannya adalah merpati itu binatang yang memiliki kesetiaan tinggi pada pasangan hidupnya.

Merpati Biru satu judul cerita novel cukup terkenal di Indonesia karena kata merpati biru bukan arti sesungguhnya, melainkan merupakan sandi tentang kehidupan mahasiswa yang memiliki pekerjaan ganda, tetapi sebenarnya rasa setia itu masih melekat di dalamnya. Hal ini tercermin dalam sikap dan perilaku tokoh utama, tokoh sentral, dan tokoh pembantu lainnya. Tokoh utama Ken memberikan pembelajaran kepada pembacanya bagaimana cara memecahkan masalah ekonomi yang mendera diri dan keluarganya serta bagaimana memecahkan masalah yang dihadapi orang lain. Ken mengajarkan bagaimana dia harus bersikap ketika menghadapi kerasnya dunia hitam dengan segala macam masalahnya. Selain itu, 
Ken berusaha dengan perjuangan yang begitu keras menumbuhkan rasa percaya diri anak berkebutuhan khusus agar bisa meraih masa depannya dengan gemilang. Demikian halnya Ken berusaha memperhatikan keutuhan rumah tangga orang yang telah menolongnya menuju kehidupan normal sebagai seorang calon sarjana. Di samping itu, Ken mengajarkan kepada pembaca norma untuk tidak menerima sesuatu yang bukan haknya sebelum dia bekerja.

Melalui tulisan ini, penulis mencoba untuk mendeskripsikan cara-cara membangun mental yang mandiri, berakhlak mulia, dan tidak harus selalu meminta belas kasihan orang lain. Di samping itu, penulis ingin menjabarkan kemandirian yang bagaimana yang harus dijalankan apabila kita dalam kesusahan hidup tanpa harus mengorbankan orang lain, tetapi masih mampu membantu orang lain.

Akhlak yang terpuji dan baik akan senantiasa terlihat nyata meskipun itu berada di dalam lembah kehinaan. Dengan bekal akhlak yang baik, manusia berusaha tetap mengingat Allah tempat mengadukan segala macam masalah yang menderanya tanpa ada rasa lelah untuk meminta agar dirinya bisa terlepas dari segala penderitaan. Meskipun masih berada di lembah kehinaan, kita harus berusaha melepaskan diri dari tempat tercela dan berusaha berbuat baik.

Tujuan dari penulisan ini adalah mendeskripsikan cara para tokoh dalam meraih satu cita-cita dengan cara kebaikan pantang menyerah. Penulis berharap agar dari deskripsi yang dijabarkan dapat memberikan gambaran yang dapat mencerahkan para pembacanya dan mendidik ke arah yang lebih baik dan berguna bagi orang lain di kemudian hari. Data tulisan ini bersumber dari novel Merpati Biru karya Achmad Munif yang diterbitkan pada tahun
2003 oleh penerbit Navila Jogyakarta.

Kerangka teori tokoh menurut Abrahams dalam Nurgiantoro (2000:163) adalah orang yang ditampilkan dalam suatu karya sastra yang oleh pembaca ditafsirkan memiliki kualitas moral dan kecenderungan tertentu seperti yang diekspresikan dalam ucapan dan tindakan. Tokoh yang akan dikaji dalam tulisan ini adalah tokoh ditinjau dari fungsinya. Tokoh ditinjau dari fungsinya dapat dibedakan menjadi tiga, yakni tokoh protagonis, tokoh antagonis, dan tokoh tritagonis. Dengan demikian, sifatsifat tokoh tersebutlah yang akan dibahas pada bagian penokohan dalam tulisan ini. Pemaparan sifat tokoh ini akan menggunakan metode tak langsung. Metode tak langsung adalah penggambaran sifat tokoh dalam novel melalui dialog, perilaku, dan sikap tokoh dalam menyikapi kehidupan yang ada di dunia ini.

Metode yang digunakan dalam penelitian ini adalah metode deskriptif. Metode ini membicarakan beberapa kemungkinan untuk memecahkan permasalahan yang aktual dengan mengemukakan data, menyusun data, menganalisis data, dan menginterpretasikannya. Selain itu, guna mendukung penulisan ini, teknik pengumpulan data yang digunakan adalah teknik studi pustaka. Adapun pendekatan yang dilakukan adalah pendekatan objektif.

Penulisan makalah ini bersumber pokok dari novel Merpati Biru karya Achmad Munif yang diterbitkan pada tahun 2003 oleh penerbit Navila Yogyakarta.

\section{Pembahasan}

Di dalam novel Merpati Biru karya Achmad Munif banyak aspek pendidikan moral yang bisa dijadikan contoh bagi masyarakat. Aspekaspek tersebut di antaranya adalah prinsip 
menjaga perasaan orang lain, hidup bersih, rapi, dan menjaga lingkungan, waspada dan tidak mudah terprovokasi, dan saling mengingatkan orang lain.

\section{a. Prinsip Menjaga Perasaan Orang lain}

Semua manusia yang terlahir ke dunia ini pada hakikatnya dibekali dengan rasa kemanusiaan oleh yang Maha Kuasa. Akan tetapi, apakah rasa itu masih hidup dan berkembang pada setiap manusia? Itu semua tergantung dari masing-masing individu. Sikap hidup yang baik yang bisa menjaga perasaan orang lain ternyata masih dimiliki dari seorang pelacur yang menurut pandangan orang adalah kotor dan sampah masyarakat. Alasannya adalah karena cara mencari rezeki mereka itu melalui jalan yang kotor dan dibenci sang Pencipta. Hal ini bisa kita lihat dalam penggalan berikut;

Ken ingat beberapa waktu lalu seorang bos dari Jakarta menawari pekerjaan. Bos itu terus terang mengatakan ingin menjadikannya isteri simpanan. Enaknya, jadi aku bekerja banya sebagai kedok. Memang aku pelacur, kotor, nista, tapi bagiku isteri simpanan lebih nista. Para lelaki boleh saja membeli tububku tanpa ikatan apa-apa, aku tidak ingin punya ikatan emosional dengan lelaki manapun yang punya isteri. Aku tidak ingin menyita cinta kasih sayang seorang suami terhadap isteri dan anakanaknya. (MB2003:81-82).

\section{b. Hidup Bersih, Rapi, dan Menjaga Lingkungan}

Kebersihan dan keindahan lingkungan erat kaitannya dengan kesehatan. Lingkungan yang bersih dan tertata rapi adalah cara menuju hidup sehat. Dewasa ini, sering kita lihat di lingkungan kita, ruangan rumah kita, bahkan kamar kita dipenuhi sampah-sampah yang berserakan di mana-mana. Padahal, kebersihan merupakan sesuatu yang dicintai Allah SWT. Sebagaimana disebutkan dalam hadis yang diriwayatkan oleh
Tarmizi RA: "Sesungguhnya Allah taala adalah baikdanmencintaikebaikan, bersihdan mencintai kebersihan, mulia dan mencintai kemuliaan, dermawan dan mencintai kedermawanan, maka bersihkanlah halaman rumahmu dan janganlah kamu menyerupai orang Yahudi." (http:// azkiahan.blogspot.co.id). Kebersihan adalah upaya manusia untuk memelihara diri dan lingkungannya dari segala yang kotor dan keji dalam rangka mewujudkan dan melestarikan kehidupan yang sehat dan nyaman. Kebersihan merupakan syarat bagi terwujudnya kesehatan dan sehat adalah salah satu faktor yang dapat memberikan kebahagiaan. Sebaliknya, kotor tidak hanya merusak keindahan, tetapi juga dapat menyebabkan timbulnya berbagai penyakit dan sakit merupakan salah satu faktor yang mengakibatkan penderitaan.

Pengertian sehat sesuai dengan UU No. 23 tentang Kesehatan adalah keadaan sejahtera dari badan, jiwa, dan sosial yang memungkinkan setiap orang hidup produktif secara sosial dan ekonomis. Terkait tentang hal tersebut, Alquran juga mempunyai istilah-istilah tersendiri dalam mengungkapkan kesehatan.

Begitu pentingnya kebersihan menurut Islam sehingga orang yang membersihkan diri atau mengusahakan kebersihan akan dicintai oleh Allah SW'T sebagaimana firmannya dalam surah Al-Baqarah ayat 222 yang berbunyi:

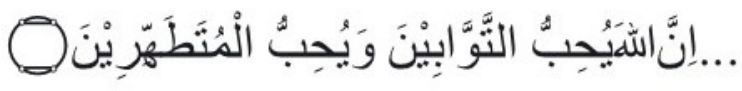

Artinya, '.... Sesungguhnya Allah menyukai orang-orang yang bertaubat dan orangorang yang menyucikan/membersihkan diri' (Al-Baqarah:222).

Kebersihan itu bersumber dari iman dan merupakan bagian dari iman. Dengan demikian, kebersihan dalam Islam mempunyai aspek 
ibadah dan aspek moral. Oleh karena itu, sering juga dipakai kata "bersuci" sebagai padanan kata "membersihkan/melakukan kebersihan." Ajaran kebersihan tidak hanya merupakan slogan atau teori belaka, melainkan dijadikan pola hidup praktis, mendidik manusia hidup bersih sepanjang masa, bahkan dikembangkan dalam hukum Islam.

Agama Islam menghendaki kebersihan yang menyeluruh dari umatnya. Untuk mencapai tujuan tersebut, agama Islam memberikan tuntutan dan petunjuk tata cara bertaharah (bersuci) dan menjaga kebersihan.

Agama Islam adalah agama yang cinta pada kebersihan. Rasulullah SAW sangat menganjurkan kepada umatnya untuk senantiasa menjaga kebersihan. Dengan menjaga kebersihan, tubuh kita akan sehat dan kuat. Dalam syariat Islam, ketika mengerjakan salat diwajibkan bagi umat Islam agar bersih dari hadas dan najis, baik badan, pakaian maupun tempat yang dipergunakan untuk salat.

Ada beberapa hadit Rasulullah SAW yang menekankan untuk menjaga kebersihan bagi umat Islam.

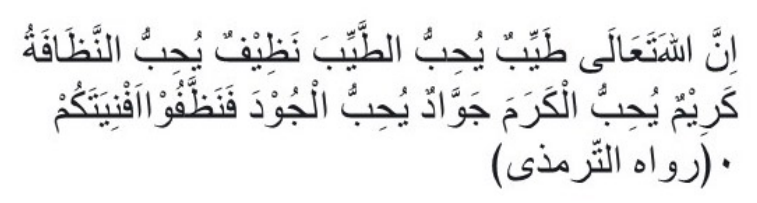

Artinya, 'Sesungguhnya Allah itu baik, mencintai kebaikan, bahwasanya Allah itu bersih, menyukai kebersihan, Dia Maha Mulia yang menyukai kemuliaan, Dia Maha Indah menyukai keindahan, karena itu bersihkan tempat-tempatmu' (HR. Turmudzi).

Hadis

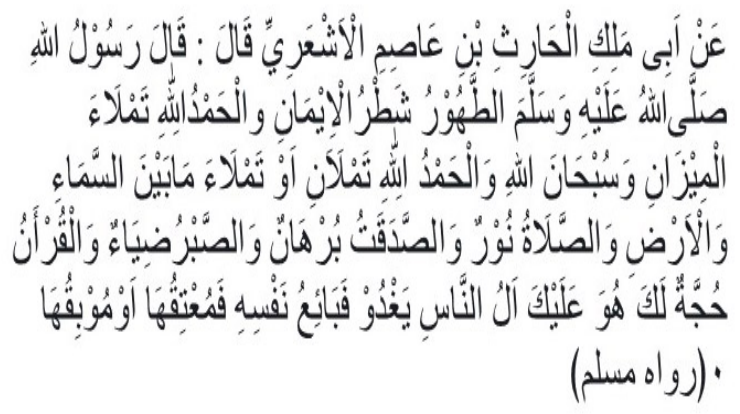

Artinya, 'Dari Abu Malik al-Haris ibn 'Asim al-Asya'arie r.a. beliau berkata: Rasulullah SAW telah bersabda, kebersihan itu sebagian daripada iman. Ucapan dzikir Al Hamdulillah memenuhi neraca timbangan. Ucapan Dzikir Subkhanallah dan Al Hamdulillah keduanya memenuhi ruangan antara langit dan bumi. Shalat itu adalah cahaya. Sedekah itu adalah pelita. Sabar itu adalah sinaran. Al-Qur'an itu adalah hujah bagimu atau hujah atasmu. Setiap manusia keluar waktu pagi, ada yang menjual dirinya, ada yang memerdekakan dirinya dan ada pula yang mencelakakan dirinya' (HR. Muslim).

Berkaitan dengan hadis tersebut ada halhal yang harus dilakukan dalam menjaga dan membiasakan diri hidup bersih. Rumah atau tempat tinggal merupakan kebutuhan pokok bagi setiap orang. Agar kita merasa nyaman dan kerasan tinggal di dalamnya, rumah harus dijaga dan dirawat, antara lain sebagai berikut.

1) Setiap pagi hari pintu dan jendela hendaknya dibuka agar terjadi sirkulasi udara.

2) Kaca-kaca pada jendela dibersihkan agar terbebas dari debu dan kotoran lainnya.

3) Perkakas rumah tangga, seperti meja, kursi, lemari, bufet, dan perkakas lain dibersihkan dan diatur penempatannya sehingga tampak bersih dan rapi.

4) Lantai dan teras rumah selalu disapu dan dipel sehingga terbebas dari kuman penyakit.

5) Kamar tidur, ruang makan, kamar mandi, 
dan ruang-ruang lain termasuk halaman dan pekarangan di sekeliling rumah hendaknya selalu dibersihkan sehingga menjadikan penghuninya menjadi sehat.

Agar rumah terlihat rindang dan alami maka dapat ditanami pohon peneduh dan tanaman hias.

Muslim yang baik menampilkan ajaran kebersihan ini dalam kehidupan sehari-hari. Oleh karena itu, orang Islam harus tampil bersih, rumahnya bersih, tempat ibadahnya bersih, lingkungan sekitarnya bersih, perkataannya sopan santun, dan perilaku sehari-harinya menyenangkan.

Kebersihan dan keindahan seperti tertuang di dalam hadis-hadis tersebut terdapat juga dalam diri pelaku dalam novel Merpati Biru ini. Kebersihan tersebut tergambar dari ruangan rumah Ken yang sempat dikagumi Tinike. Hal ini terlihat pada cuplikan berikut.

"Tinike memandangi sekeliling ruangan. Ia tertarik pada penataan ruang tamu tersebut. Ruangnya tidak terlalu luas, tetapi ditata dengan apik.Padakeempatdindingnyaterpasanglukisan dan hiasan. Di dinding yang menghadap keluar terdapat lukisan pemandangan berukuran besar, nyaris selebar dinding itu sendiri. Pada dinding kiri terdapat lukisan seorang wanita cantik. yang sedang membatik. Di kedua dinding yang lain dipasang hiasan yang terbuat dari bamboo. Dipojok ruangan terdapat rak penub buku. Di pojok yang lain ada bonsai beringin putib. Di dekatnya ada tempat koran dan majalah dari rotan. Di dekatnya lagi ada kipas angin. Di meja terdapat asbak berbentuk sepatu wanita. Bagi Tinike secara keseluruban, ruangan itu menarik dan rupanya ditata menurut selera yang tidak terlalu tinggi, tetapi tidak kampungan." (MB2003:86).

Bila mengaitkan dengan hadis-hadis yang disebutkan terdahulu, tenyata wanita yang berprofesi sebagai wanita panggilan masih memiliki rasa keimanan dengan cara tetap menjaga kebersihan lingkungan tempat tinggalnya dengan cara menata ruang tamu sedemikian asri.

\section{c. Waspada dan Tidak Mudah Terprovokasi}

Manusia bijak dan arif, yakni manusia yang mampu mengendalikan diri dan senantiasa waspada menghadapi sesuatu bujuk dan rayu dari orang lain. Bujuk rayu biasanya terasa sangat manis dan begitu menggiurkan. Akan tetapi, kita sebagai manusia harus tahu dan paham apakah bujukan dari pihak lain itu akan menuju kebaikan atau malah sebaliknya, yakni menjerumuskan ke arah yang fatal akibatnya sehingga penyesalanlah yang akan terjadi bila kita tidak waspada dan mudah terprovokasi. Sikap waspada dan tidak terprovokasi ini bisa dilihat dalam cuplikan berikut ini.

"Ken memandang Tinike. Sampai demikian jauh, pikirnya. Aku harus bati-hati. Aku belum tabu betul siapa Tinile. Dan perempuan itu mengajaknya untuk bermain api. Ia curiga, jangan-jangan ada di pibak lain yang berdiri di belakang Tinike." (MB2003:88).

Membaca cuplikan tersebut sangatlah jelas bilaseorang tokoh Ken benar-benarmemberikan pembelajaran pada kita bahwa sikap hatihati sangat dibutuhkan dalam kehidupan ini. Alasannya jelas bahwa segala sesuatu yang akan kita kerjakan pasti mengandung risiko. Apalagi ini suatu ajakan pekerjaan dari orang yang baru dikenalnya, kita harus lebih ekstra hati-hati bisabisa kita nantinya terjerumus ke hal yang tidak terpuji.

\section{d. Saling Mengingatkan Orang Lain}

Para ahli salaf mengatakan, telah disepakati bahwa amar makruf nahi munkar itu wajib bagi insan. Namun, wajibnya adalah fardu kifayah, hal ini sebagaimana jihad dan mempelajari 
ilmu tertentu serta yang lainnya. Yang dimaksud fardu kifayah adalah jika sebagian telah memenubi kewajiban ini, maka yang lain gugur kewajibannya. Walaupun pahalanya akan diraih oleh orang yang mengerjakannya, begitu pula oleh orang yang asalnya mampu, saat itu tidak bisa untuk melakukan amar makruf nahi mungkar yang diwajibkan. Jika ada orang yang ingin beramar makruf nahi mungkar, wajib bagi yang lain untuk membantunya hingga maksudnya yang Allah dan rasul-Nya perintahkan tercapai. Sikap saling mengingatkan terhadap orang lain dalam kehidupan sangat dibutuhkan. Hal ini untuk kebaikan bersama agar orang lain juga tetap dalam jalur yang tepat sehingga tidak ada yang terjerumus. Apalagi bila yang kita ingatkan itu adalah sahabat kita, orang terdekat di sekitar kita sehingga saling mengingatkan wajib hukumnya. Hal ini juga termaktub dalam Alquran surat (QS. Al Maidah: 2) Allah taala berfirman,

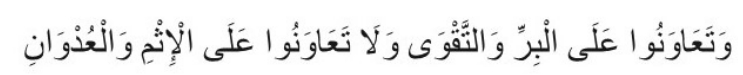

'Dan tolong-menolonglah kamu dalam (mengerjakan) kebajikan dan takwa, dan jangan tolong-menolong dalam berbuat dosa dan melampani batas.' ini:

Hal ini bisa dilihat dalam cuplikan berikut

"Sebagai teman, saya hanya bisa mengingatkan. Dik Tinjangan bermain api. Nanti anda sendiri yang susah. Kasusnya bisa melebar. Sebab bisa terjadi kontra unjuk rasa. Sebab anak-anak" Suara Mahasiswa" bukan tanpa pengaruh. Orang yang berpikiran waras akan lebih berpihak pada mereka. Tidak usah macammacam Dik Tin. Kita sadari saja babwa kita ini tidak bener. Dengan begitu masalabnya tidak akan meluas." (MB2003:90).

Bila kita simak kalimat dari kutipan novel Merpati Biru tersebut, jelaslah bahwa ada hubungannya dengan Alquran Surat Almaidah ayat 2, yakni manusia harus senantiasa berbuat baik dengan saling mengingatkan antara teman yang satu dan teman yang lainnya untuk melakukan hal-hal kebaikan dan meninggalkan hal-hal buruk. Nasihat tersebut akan berguna untuk diri kita dan orang lain sekiranya akan menjerumuskan ke lembah kehinaan untuk dirinya sendiri ataupun orang lain. Bila hal ini dilaksanakan dengan terus-menerus dan dilakukan oleh semua orang amanlah dunia ini.

\section{Simpulan dan Rekomendasi}

Keteladanan sikap ternyata tidaklah selamanya berasal dari orang-orang selalu suci. Akan tetapi, bisa saja datangnya dari bekas orang-orang yang tadinya berlumuran dosa yang telah mendapat rahmat dan hidayah dari Allah Swt. Hal ini sudah dipertegas penulis dari pembahasan sebelumnya. Jadi, intinya hidup sebagai manusia yang memiliki hati nurani. Janganlah selalu memandang rendah orang yang sedang dalam kubangan dosa karena suatu saat jika sudah mendapatkan hidayah Allah Swt pasti akan kembali ke jalan yang benar.

Untuk pembaca, hendaklah senantiasa belajar dari buku-buku apa saja guna menambah wawasan keilmuan. Buku merupakan jendela dunia yang akan bisa mengubah jalan pikiran seseorang menuju yang lebih baik. 


\section{Daftar Pustaka}

Koentjaraningrat. 1984. Kebudayaan Mentalitas dan Pembangunan. Jakarta: PT Gramedia.

Munif,Achkmad.2003.MerpatiBiru. Yogyakarta: Navila.

Nurgiantoro, Burhan. 1995. Teori Pengkajian Fiksi. Jogyakarta: Gajahmada.

Rahmanto, B. 1988. Metodologi Pengajaran Sastra: Pegangan Guru Pengajar Sastra. Yogyakarta: Kanisius.
Wellek, Rene dan Austin Warren. 1989. Pengantar Teori Sastra (diindonesiakan oleh Melani Budianta). Jakarta: Gramedia.

... 1998. Al Quran dan Terjemahannya.Semarang: Asy-Syifa.

https://www.facebook.com/Hisbah99/ posts $/ 467046243393223$

http://azkiahan.blogspot.co.id/2013/03/ menjaga-kebersihan.html 